Komparasi Tentang Pembagian Harta Waris Untuk. Anak Luar Nikah....

\title{
KOMPARASI TENTANG PEMBAGIAN HARTA WARIS UNTUK ANAK LUAR NIKAH DALAM KUH PERDATA DAN KOMPILASI HUKUM ISLAM
}

\author{
Oleh. Ipandang \\ Dosen IAIN Kendari \\ Email: ipandangiainkendari@gmail.com
}

\begin{abstract}
This paper examines the comparison of the share of inheritance for children with foreign marriage in the Civil law and the compilation of Islamic laws. Basically, any applicable law regarding inheritance has its own provisions or arrangements regarding the boundaries of the Heritage division of Justice. Similarly, in the Civil Law and the compilation of Islamic laws. In both regulations, there are similarities and differences in inheritance provisions for foreign children. But despite the difference, the essence has the same purpose that the two aim to give welfare and justice to a recognized child of marriage.
\end{abstract}

Keywords: Comparison, Estate, Child Marriage, KUHP, and HKI

\section{PENDAHULUAN}

Pasal 1 Undang-undang No. 1 Tahun 1974 tentang Perkawinan menjelaskan bahwa perkawinan adalah ikatan lahir batin antara seorang pria dan wanita sebagai suami istri dengan tujuan membentuk keluarga (rumah tangga) yang bahagia dan kekal berdasarkan Ketuhanan Yang Maha Esa. ${ }^{1}$ Dari bunyi Pasal 1 Undang-Undang Nomor 1 Tahun 1974 tersebut di atas, tersimpul suatu rumusan arti dan tujuan dari perkawinan. Arti "perkawinan" dimaksud adalah ikatan lahir bathin antara seorang pria dengan seorang wanita sebagai suami istri, sedangkan "tujuan" perkawinan dimaksud adalah membentuk keluarga (rumah tangga) yang bahagia dan kekal berdasarkan Ketuhanan Yang Maha Esa.

Semangat tujuan perkawinan tersebut sejalan dengan firman Allah dalam al-Qur'an surat al-Rūm ayat 21:

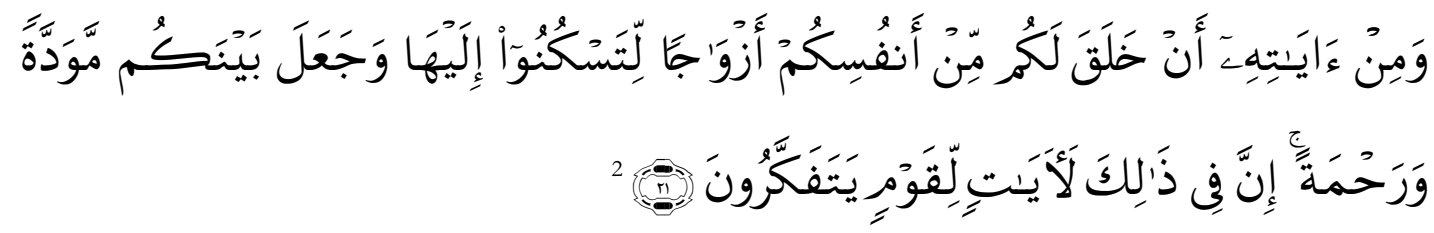

Artinya :

"Dan diantara tanda-tanda kekuasaan-Nya ialah Dia menciptakan isteri-isteri dari jenismu sediri supaya kamu cenderung dan merasa tentram kepadanya dan dijadikannya diantara

\footnotetext{
${ }^{1}$ Soesilo dan Pramudji R., Undang-undang RI No. 1 Tabu 1974 tentang Perkawinan (T.tp: Rhedbook Publisher, 2008), 461.

${ }^{2}$ QS. Al-Rūm (30): 21.
}

Falasifa, Vol. 11 Nomor 1 Maret 2020 | 185 


\section{Ipandang}

kamu kasih sayang, sesungguhnya pada yang demikian itu benar-benar terdapat tanda-tanda bagi kaum yang berfikir". ${ }^{3}$

Makna dan arti dari perkawinan menjadi lebih dalam karena selain melibatkan kedua keluarga juga lebih berarti untuk melanjutkan keturunan yang merupakan hal penting dari gagasan melaksanakan perkawinan. Kehadiran seorang anak merupakan kebahagiaan dan kesejahteraan bagi seorang ibu maupun keluarganya karena anak merupakan buah perkawinan dan sebagai landasan keturunan. Untuk membentuk keluarga yang bahagia dan sejahtera, maka orang tua membina dan memelihara anaknya dengan cinta kasih, perhatian yang cukup termasuk pendidikan, kesehatan dan kecakapan.

Anak sebagai fitrah Tuhan Yang Maha Esa perlu mendapatkan perawatan sebaik-baiknya dan merupakan tunas-tunas bangsa yang akan meneruskan cita-cita bangsa yaitu mewujudkan suatu masyarakat yang adil dan makmur. Agar anak mampu memikul tanggung jawabnya di masa depan, maka perlu mendapat kesempatan yang seluas-luasnya untuk tumbuh dan berkembang secara normal baik jasmani, rohani maupun sosial. Menurut Kitab Undangundang Hukum Perdata, dengan perkawinan suami istri memperoleh keturunan. Yang dimaksud dengan "keturunan" disini adalah hubungan darah antara bapak, ibu dan anakanaknya. Jadi antara bapak, ibu serta anak terdapat hubungan biologis. Anak-anak yang dilahirkan dari hubungan biologis dan ditumbuhkan sepanjang perkawinan dinamakan anakanak sah (wettige of echte kinderen). ${ }^{4}$

Perkawinan merupakan usaha untuk menjaga kelestarian hidup manusia dan melindungi nasab. Namun tidak jarang perlindungan nasab itu dinodai dengan perzinahan dan anak sebagai komponen keluarga apabila berasal dari hasil hubungan luar nikah akan terajadi kepincangankepincangan status hukum. Dalam pandangan Islam setiap manusia dilahirkan dalam keadaan suci dan bersih termasuk anak luar nikah. Kehadiran seorang anak di luar perkawinan akan menimbulkan suatu permasalahan yang cukup memprihatinkan baik bagi perempuan yang melahirkan maupun bagi lingkungan masyarakat setempat. Dimana dengan adanya anak yang lahir di luar perkawinan akan menimbulkan banyak pertentangan-pertentangan diantara keluarga maupun di lingkungan masyarakat mengenai kedudukan hak dan kewajiban anak tersebut. Kehadiran anak luar nikah oleh orang tuanya diterima dalam berbagai sikap, ada yang

\footnotetext{
3 Tim Pelaksana Pentashihan Mushaf al-Qur'an, Mushaf 'Aisyah :Al-Qur'an dan Terjemah untuk. Wanita (Bandung: Hilal, 2010), 406.

${ }^{4}$ Rr. Murdiningsih, Tesis: Peranan Notaris (Jakarta: FH UI, 2009 ).
}

186 | Falasifa, Vol. 11 Nomor 1 Maret 2020 
bersikap wajar, begitu pula penerimaan yang dilakukan masyarakat, dan masyarakat menerima anak yang lahir di luar nikah tersebut selalu dengan sikap kurang wajar.

Anak yang dilahirkan oleh seorang perempuan, sedangkan perempuan tersebut tidak berada dalam ikatan perkawinan yang sah dengan pria yang menghamilinya dinamakan anak luar nikah. ${ }^{5}$ Berdasarkan pasal 272 KUH Perdata ${ }^{6}$, pengertian anak luar nikah dibagi menjadi dua, yaitu pengertian dalam arti luas dan sempit. Anak luar nikah dalam arti luas meliputi anak zina, anak sumbang, ${ }^{7}$ dan anak luar nikah lainnya. Sedangkan anak luar nikah dalam arti sempit adalah anak yang lahir di luar perkawinan yang sah. Sedangkan di dalam Kompilasi Hukum Islam tidak menentukan secara khusus dan pasti tentang pengelompokan jenis anak, sebagaimana pengelompokan yang terdapat dalam Hukum Perdata. Namun secara implisit, Kompilasi Hukum Islam menyinggung tentang status dan kedudukan anak luar nikah pada pasal 100 dan pasal 186.

Dalam hukum adat, pada umumnya anak di luar nikah disebut anak haram, tidak mempunyai hubungan perdata dengan laki-laki yang menghamili ibunya. Hukum adat melihat bahwa anak luar nikah merupakan cela, sehingga lembaga pengakuan sebagaimana dalam hukum perdata dan yang dianjurkan oleh hukum Islam sebaiknya dihindari. Bagi hukum adat yang penting adanya perkawinan yang sah untuk menutupi aib, meskipun setelah perkawinan dilaksanakan pengantin pria tidak pernah kembali lagi ke rumah pengantin wanita. Dengan perkawinan anak yang lahir dari wanita hamil tersebut sudah mempunyai ayah secara resmi, seingga tidak disebut sebagai anak haram atau anak haram jadah yang tentu akan berpengaruh buruk pada si anak. ${ }^{8}$

Menurut Undang-undang Perkawinan Pasal 43 ayat 1, anak yang dilahirkan di luar perkawinan hanya mempunyai hubungan perdata dengan ibunya dan keluarga ibunya. Artinya, si anak tidak mempunyai hubungan hukum dengan ayah biologisnya, baik yang berkenaan dengan pendidikan maupun dalam hal kewarisan.

\section{PEMBAHASAN}

\footnotetext{
5 Abdul Manan, Aneka Masalah Hukum Perdata Islam Di Indonesia (Jakarta: Kencana Prenada Media, 2008$), 80$.

${ }^{6}$ Soesilo dan Pramudji R., Kitab Undang-undang Hukum Perdata (T.tp: Rhedbook Publisher, 2008), 62.

${ }^{7}$ Anak yang lahir dari seorang ibu yang dilarang kawin menurut Undang-undang dengan lelaki yang membenihkannya, seperti saudara kandung atau sepersusuan.

8 Abdul Manan, Aneka Masalab Hukum, 77.
} 


\section{Ipandang}

\section{Kewarisan Dalam KUH Perdata}

Hukum waris dalam KUH Perdata (Burgerlijk Wetboek) diartikan: kesemua kaidah hukum yang mengatur nasib kekayaan seseorang setelah ia meninggal dunia dan menentukan siapa orang yang dapat menerimanya. ${ }^{9}$ Setiap orang yang meninggal dan meninggalkan harta warisan disebut sebagai pewaris, sedangkan orang yang akan menerima harta warisan yang ditinggalkan disebut sebagai ahli waris.

Menurut H.M. Ramulyo dalam bukunya "Perbandingan Hukum Kewarisan Islam dengan Kewarisan Kitab Undang-undang Hukum Perdata Barat" menerangkan bahwa apabila membicarakan masalah warisan maka akan sampai pada empat masalah pokok dimana yang satu dengan yang lainnya tidak dapat terpisahkan. Masalah pokok tersebut adalah: pertama, adanya seseorang yang meninggal dunia; kedua, ia meninggalkan harta peninggalan, masalah pokok yang ketiga adalah meninggalkan orang-orang yang mengurusi dan berhak atas harta peniggalan tersebut (ahli waris), dan masalah pokok yang keempat yang tidak kalah pentingnya adalah keharusan adanya hukum kewarisan yang menentukan siapa saja ahli waris dan berapa bagian masing-masing. ${ }^{10}$

Bila seorang manusia sebagai individu meninggal dunia maka akan timbul pertanyaan bagaimana hubungan yang meninggal dunia itu dengan yang ditinggalkan serta kewajibankewajiban yang harus dipenuhi, terutama dalam masalah kekayaan (vermongensrecht) dari orang yang meninggal dunia. Demikian juga membutuhkan aturan-aturan yang mengatur bagaimana tentang hubungan yang meninggal dunia dengan harta benda yang ditinggalkan, siapa yang mengurus dan mewarisi, dan bagaimana cara peralihan harta tersebut kepada yang masih hidup. Jadi masalah yang timbul dalam kewarisan adalah masalah harta benda (kekayaan) dari orang yang meninggal dunia dengan orang-orang yang ditinggalkan.

\section{Dasar Hukum Kewarisan}

Hukum waris dalam KUH Perdata diatur dalam Buku II Bab 12 dan 16, terutama Pasal 528 tentang hak mewaris diidentikkan dengan kebendaan, dan ketentuan Pasal 584 menyangkut hak waris sebagai salah satu cara untuk memperoleh hak kebendaan. Penempatan hukum kewarisan dalam Buku II KUH Perdata ini menimbulkan pro dan kontra di kalangan ahli hukum, karena mereka berpendapat bahwa dalam hukum kewarisan tidak hanya tampak

\footnotetext{
9 Tamakiran S., Asas-asas Hukum Waris Menurut Tiga Sistim Hukum (Bandung: Pionir Jaya, 2000), 24.

${ }^{10}$ M. Idris Ramulyo, Perbandingan Hukum Kewarisan Islam dengan Kewarisan Kitab Undang-undang Hukum Perdata Barat, Edisi Revisi (Jakarata: Sinar Grafika, 2004), 82.
}

188 | Falasifa, Vol. 11 Nomor 1 Maret 2020 
sebagai hukum benda saja, tetapi terkait beberapa aspek lainnya, misalnya hukum perorangan dan kekelurgaan.

Ada banyak asas dan dasar hukum waris KUH Perdata (Burgerlijk Wetboek) yang berpengaruh terhadap pembagian warisan. Dengan mengenal dan memahami makna hakiki dari asas-asas dan dasar-dasar tersebut, pembagian harta warisan kepada ahli waris yang berhak besar kemungkinan akan mencapai hasil yang adil. Diantara asas-asas kewarisan tersebut antara lain:

1) Hukum yang Bersifat Mengatur (Aanvullend Recht)

Hukum waris Burgerlijk Wetboek termasuk dalam lapangan atau bidang hukum perdata. Semua cabang hukum yang termasuk dalam bidang hukum perdata memiliki kesamaan sifat dasar, antara lain bersifat mengatur dan tidak ada unsur paksaan. Namun untuk hukum waris Burgerlijk Wetboek, meskipun letaknya dalam hukum perdata, tetapi ternyata di dalamnya terdapat unsur paksaan. Misalnya, ketentuan yang memberikan hak mutlak kepada ahli waris tertentu atas sejumlah tertentu dari harta warisan atau ketentuan yang melarang pewaris sewaktu hidupnya untuk membuat ketetapan terhadap sejumlah tertentu dari hartanya. Misal di masa hidupnya pewaris telah membuat ketetapan seperti menghibahkan sejumlah tertentu dari hartanya yang dilarang itu, maka penerima hibah mempunyai kewajiban hukum untuk mengembalikan harta yang telah dihibahkan tersebut ke dalam harta warisan guna memenuhi hak mutlak ahli waris yang mempunyai hak mutlak. ${ }^{11}$

Unsur paksaan dalam hukum waris Burgerlijk Wetboek berbeda dengan unsur paksaan pada hukum yang bersifat memaksa seperti hukum pidana, bahwa pelanggaran terhadap unsur paksaan dalam hukum waris Burgerlijk Wetboek tidak berakibat pidana, melainkan hanya berupa konsekuensi sebagaimana contoh di atas. Konsekuensi dari hukum waris Burgerlijk Wetboek sebagai salah satu cabang hukum perdata yang bersifat mengatur, maka apa saja yang diperbuat oleh pewaris semasa hidup terhadap hartanya adalah kewenangannya. Namun jika

11 Anisitus Amanat, Membagi Warisan Berdasarkan Pasal-pasal Hukum Perdata BW (Jakarta: PT Raja Grafindo Persada, 2000), 1-2. 


\section{Ipandang}

pelaksanaan kewenangan itu melampaui batas yang diperkenankan, maka akan ada resiko hukum di kemudian hari setelah ia meninggal dunia. ${ }^{12}$

2) Hanya Berlaku Untuk WNI Golongan Tertentu

Masih berlaku tidaknya Burgerlijk Wetboek (BW) yang diterjemahkan dalam Kitab Undang-undang Hukum Perdata (KUH Perdata) di Indonesia, haruslah terlebih dahulu dilihat penggolongan penduduk pada masa pemerintahan Hindia Belanda dan hukum yang berlaku pada masing-masing golongan tersebut. Pada masa lalu penduduk di Indonesia digolong-golongkan menurut ketentuan Pasal 131 jo. Pasal 163 Indische Staatsregeling, yaitu:

a) Orang-orang Belanda;

b) Orang-orang Eropa yang lain;

c) Orang-orang Jepang, dan orang-orang lain yang tidak termasuk dalam kelompok satu dan dua yang tunduk pada hukum yang mempunyai asasasas hukum keluarga yang sama;

d) Orang-orang yang lahir di Indonesia, yang sah ataupun diakui secara sah dan keturunan lebih lanjut dari orang-orang yang termasuk kelompok 2 dan $3 .^{13}$

Berdasarkan pendapat Idris Ramulyo, dikatakan bahwa menurut Staatsblaad 1925 Nomor 145 jo. 447 yang telah diubah, terakhir dengan Staatsblaad1929 No. 221 Pasal 131 jo. Pasal 163, hukum kewarisan yang diatur dalam KUH Perdata diberlakukan bagi orang-orang Eropa dan mereka yang yang dipersamakan dengan orang-orang Eropa tersebut. Dengan Staatsblaad 1917 Nomor 129 jo. Staatsblaad 1924 Nomor 557 hukum kewarisan dalam KUH Perdata diperlakukan bagi orang-orang Timur Asing Tionghoa. Dan berdasarkan Staatsblaad 1917 Nomor 12, tentang penundukan diri terhadap hukum Eropa maka bagi orang-orang Indonesia dimungkinka pula menggunakan hukum kewarisan yang tertuang dalam KUH Perdata (Burgerlijk Wetboek) yang diberlakukan pada:

a) Orang-orang Eropa dan mereka yang dipersamakan dengan orang-orang Eropa, misalnya Inggris, Jerman, Prancis, Amerika dan termasuk orang-orang Jepang;

b) Orang-orang Timur Asing Tionghoa;

12 Anisitus Amanat, Membagi Warisan Berdasarkan, 2-3.

13 Surini Ahlan Syarif. Hukum Kewarisan Perdata Barat, 3.

190 | Falasifa, Vol. 11 Nomor 1 Maret 2020 
c) Orang-orang Timur Asing lainnya dan Orang-orang pribumi yang menundukkan diri terhadap hukum. ${ }^{14}$

\section{Sebab-sebab Menerima Warisan}

Dalam hukum waris perdata terdapat 2 (dua) unsur untuk memperoleh harta warisan. Unsure-unsur tersebut adalah:

1) Unsur individual (menyangkut diri pribadi seseorang)

Pada prinsipnya seorang pemilik atas suatu benda mempunyai kebebasan yang seluasluasnya sebagai individu untuk berbuat apa saja atas benda yang dimilikinya. Misalnya menghibahkan ataupun memberikan harta kekayaannya kepada orang lain menurut kehendaknya.

2) Unsur sosial (menyangkut kepentingan bersama)

Perbuatan yang dilakukan oleh seseorang pemilik harta kekayaan sebagaimanad dijelaskan dalam unsur individual, undang-undang memberikan pembatasanpembatasan terhadap kebebasan pewaris demi kepentingan ahli waris yang sangat dekat yang bertujuan untuk melindungi kepentingan mereka. ${ }^{15}$

Adapun syarat-syarat seseorang menerima warisan diatur dalam Buku kedua KUH Perdata yaitu:

a) Ada orang yang meninggal dunia. Pasal $830 \mathrm{KUH}$ Perdata menyebutkan bahwa pewarisan hanya berlangsung karena kematian. Kematian disini adalah kematian alamiah (wajar).

b) Untuk memperoleh harta peninggalan ahli waris harus hidup pada saat pewaris meninggal. ${ }^{16}$

\section{Penggolongan Ahli Waris dan Bagiannya Masing-masing}

Menurut KUH Perdata (Burgerlijk Wetboek), ahli waris dibagi menjadi 4 (empat) golongan: ${ }^{17}$

1) Golongan I, yaitu anak-anak dan keturunannya, termasuk suami-istri. Mereka menerima bagian yang sama. Hal ini diatur dalam Pasal $852 \mathrm{KUH}$ Perdata yang berbunyi: "pembagian antara anak-anak dan janda adalah sama. Apabila salah

\footnotetext{
14 M. Idris Ramulyo, Perbandingan Hukum Kewarisan, 60.

${ }^{15}$ Surini Ahlan Syarif, Hukum Kewarisan Perdata Barat 13.

$16 \mathrm{Ibid}, 14$.

17 Tamakiran S., Asas-asas Hukum Waris, 36.
} 


\section{Ipandang}

seorang anak ini meninggal lebih dahulu, maka digantikan oleh anak dari anak yang meninggal itu atau cucu dari si peninggal warisan”.

Anak-anak mewaris dalam derajat pertama, artinya mereka mewaris kepala demi kepala. Mereka masing-masing mempunyai bagian yang sama besar. Hal ini sesuai dengan Pasal 852 Ayat 2 KUH Perdata yang mengatur tentang asas persamaan, yaitu dimana hak mewaris masih diteruskan dengan menetapkan anakanak atau sekalian keturunan mereka mewaris dari pewaris, meskipun mereka lahir dari perkawinan yang lain.

Dalam Pasal 852a KUH Perdata ditentukan bahwa bagian suami atau istri yang hidup terlama adalah sama dengan bagian anak. Ketentuan yang mempersamakan bagian suami istri yang hidup terlama dengan anak, hanya berlaku dalam pewarisan karena kematian. Apabila si pewaris meninggalkan seorang suami atau istri yang hidup terlama dan tidak meninggalkan keturunan, maka suami atau istri yang hidup terlama ini berhak atas seluruh warisan. Suami atau istri mengenyampingkan orang tua, saudara laki da perempuan seandainya mereka masih ada. suami atau istri yang hidup terlama ini tampil sebagai ahli waris berdasarkan keutamaan, sehingga menutup golongan lain. ${ }^{18}$

2) Golongan II, yaitu orang tua dan saudara-saudara. Dalam hal ini diadakan pembagian yang sama baik untuk golongan ahli waris di garis ayah maupun untuk ahli waris di garis ibu.

Golongan II ini baru menerima warisan apabila Golongan I tidak ada dan Golongan II ini terdiri dari orang tua dan saudara-saudara sekandung dari si peninggal warisan. Mereka bersama-sama mendapat warisan, meskipun saudarasaudara itu adalah anak dari orang tua si peninggal warisan. Pembagian harta warisan untuk ahli waris Golongan II ini diatur dalam pasal-pasal berikut ini:

a) Pasal $854 \mathrm{KUH}$ Perdata

Apabila seseorang meninggal dunia, dengan tidak meninggalkan keturunan maupun suami istri, sedangkan bapak dan ibunya masih hidup, maka masingmasing mereka mendapatkan sepertiga dari warisan, jika si meninggal hanya meninggalkan seorang saudara laki atau perempuan, yang mana mendapat

18 Surini Ahlan Syarif, Hukum Kewarisan Perdata Barat, 53-54.

192 | Falasifa, Vol. 11 Nomor 1 Maret 2020 
Komparasi Tentang Pembagian Harta Waris Untuk. Anak Luar Nikah....

sepertiga selebihnya. Si bapak dan si ibu masing-masing mendapat seperempat, jika si meninggal meninggalkan lebih dari seorang saudara laki atau perempuan, sedangkan dua perempat bagian selebihnya menjadi bagian saudara laki atau perempuan itu.

Dari pasal tersebut dapat ditarik kesimpulanbahwa seorang yang meninggal dunia tanpa meninggalkan keturunan maupun suami istri, berarti sudah tidak ada golongan I, maka golongan II yaitu bapak, ibu dan saudara-saudara tampil sebagai ahli waris. Besarnya bagian masing-masing adalah jika bapak dan ibu mewaris bersama seoran saudara baik laki-laki maupun perempuan, mereka masing-masing mendapatkan1/3 harta warisan. Sedangkan apabila ternyata pewaris mempunyai saudara lebih dari 2 (dua) orang, maka bapak dan ibu tidak boleh mendapat bagian kurang dari 1/4 (seperempat) harta warisan. Bagian bapak dan ibu tersebut harus dikeluakan terlebih dahulu, setelah itu sisanya dibagikan diantara saudara-saudara pewaris.

b) Pasal $855 \mathrm{KUH}$ Perdata

Dalam pasal ini mengatur bagian bapak atau ibu yang hidup terlama. Jadi disini hanya ada bapak atau ibu dan ada saudara. Besarnya bagian bapa atau ibu berdasarkan pasal ini adalah $1 / 2$ (setengah) dari warisan jika si meninggal hanya meninggalkan seorang saudara perempuan atau laki-laki. Apabila jumlah saudara pewaris 2 (dua) atau lebih maka bagian ayah atau ibu seperempat dari warisan, dan selebihnya adalah untuk saudara-saudara laki atau perempuan tersebut.

c) Pasal 856 KUH Perdata Apabila bapak ataupun ibu pewaris telah meninggal dunia maka bagian saudara-saudara pewaris adalah seluruh warisan tanpa adanya pembedaan laki-laki atau perempuan.

d) Pasal 857 KUH Perdata

Dalam pasal ini dijelaskan bahwa dalam pembagian warisan golongan II apabila terdapat maka pembagian warisannya disamakan tanpa membedakan apakah itu saudara sekandung atau saudara seayah atau seibu. ${ }^{19}$

${ }^{19}$ Ibid, 59-61. 


\section{Ipandang}

3) Golongan III, yaitu sekalian keluarga sedarah dalam garis ayah dan golongan dalam garis ibu. Golongan III ini terdiri keluarga sedarah dari garis ayah dan keluarga sedarah dari garis ibu. Maka warisan dibagi dua terlebih dahulu, bagian pertama untuk sanak keluarga dari pancar ayah dari yang meninggal, dan sebagian lagi untuk sanak keluarga dari pancar ibu. Bagian dari pancar ibu jatuh pada ayah dan ibu dari si ibu, dan bagian pancar ayah jatuh pada ayah dan ibu si ayah.

Pembagian warisan untuk Golongan III ini diaatur dalam Pasal 853 KUH Perdata yang mengatakan bahwa ahli waris golongan III ini terdiri dari sekalian keluarga dalam garis lurus ke atas, baik garis lurus ayah maupun ibu. Berdasarkan Pasal 853 ini maka warisan dibagi dalam 2 bagian bagian terlebih dahulu (kloving). Satu bagian untuk keluarga sedarah dalam garis ayah lurus ke atas. Satu bagian untuk keluarga sedarah dalam garis ibu lurus ke atas. Arti pemecahan (kloving) adalah bahwa tiap-tiap bagian atau dalam tiap-tiap garis, pewarisan dilaksanakan seakan-akan merupakan kesatuan yang berdiri sendiri.

Dalam pewarisan garis lurus ke atas tidak dikenal penggantian tempat. Oleh karena keluarga yang dekat menutup keluarga yang perderajatannya lebih jauhlebih dari pewaris (Pasal 843 KUH Perdata).

4) Golongan IV, yaitu sekalian sekeluarga dalam salah satu garis ke atas yang masih hidup dan golongan anak saudara dalam garis lain. Ahli waris golongan IV ini adalah keluarga sedarah lainnya dalam garis menyimpang sampai derajat keenam.

Golongan IV diatur dalam Pasal 858 KUH Perdata. Dalam Pasal ini menyatakan bahwa apabila tidak ada saudara laki-laki dan perempuan dan juga tidak ada keluarga sedarah yang masih hidup dalam salah satu garis ke atas, maka separuh harta peninggalan menjadi bagian dari keluarga sedarah dalam garis ke atas yang masih hidup, sedangkan yang separuh lagi menjadi bagian keluarga sedarah garis ke samping dari garis garis ke atas lainnya, kecuali dalam hal yang tercantum dalam pasal berikut. Pasal 858 tersebut dapat diartikan sebagai berikut:

a) Apabila tidak ada saudara laki-laki dan permpuan (berate Golongan II); 
Komparasi Tentang Pembagian Harta Waris Untuk. Anak Luar Nikah....

b) Saudara dalam salah satu garis lurus ke atas (berarti Golongan III);

c) Harta warisan dibagi dua, yaitu:

- $\quad 1 / 2$ bagian warisan (kloving), menjadi bagian keluarga sedarah dalam garis lurus ke atas yang masih hidup

- $1 / 2$ bagian lainnya, kecuali dalam hal tersebut dalam pasal berikut, menjadi bagian para sanak saudara dalam garis yang lain.

Sanak saudara dalam garis yang lain adalah paman dan bibi serta sekalian keturunan mereka, yang telah meninggal dunia lebih dahulu dari pewaris, mereka adalah ahli waris golongan keempat. ${ }^{20}$

Menurut KUH Perdata, ada dua cara untuk mendapatkan warisan, yaitu:

1) Ahli waris menurut ketentuan undang-undang atau "ab intestato";

2) Karena ditunjuk dalam surat wasiat (testamen) atau dinamakan mewarisi secara "testamentair'.

Dalam Pasal 875 KUH Perdata, yang dimaksud dengan testament atau kehendak terakhir adalah suatu akta yang memuat pernyataan seseorang tentang apa yang dikehendaki agar terjadi setelah ia meninggal dunia dan olehnya dapat dicabut kembali. Ketetapan dengan surat wasiat dalam Pasal 876 KUH Perdata terdiri dari 2 (dua) cara, yaitu:

a) Erfstelling, yaitu memberikan wasiat dengan tidak ditentukan bendanya secara tertentu. Erfstelling ini diatur di dalam Pasal 954 KUH Perdata dimana pengertian Erfstelling disini diartikan suatu ketetapan kehendak terakhir pada mana si pewaris memberikan harta kekayaan yang akan ditinggalkan setelah ia meninggal kepada seorang atau beberapa orang, baik untuk seluruhnya maupun untuk bagian seimbang seperti misalnya seperdua, sepertiga dan sebagainya.

b) Legaat, yaitu memberikan wasiat yang bendanya dapat ditentukan. Legaat (hibah wasiat) ini diatur dalam Pasal 957 KUH Perdata yang mengatakan bahwa hibah wasiat adalah suatu penetapan (beschikking) yang khusus, dengan mana si pewaris memberikan suatu atau beberapa barang tertentu kepada seorang atau beberapa orang atau memberikan

${ }^{20}$ Ibid, 77. 


\section{Ipandang}

seluruh barang-barangnya dari jenis tertentu, misalnya barang-barang bergerak atau memberikan hak pakai hasil atau seluruh sebagian harta peninggalannya.

Dengan demikian, wasiat itu merupakan kehendak terakhir dari seseorang/pernyataan yang sepihak yang setiap waktu dapat dicabut kembali. Namun dalam pembuatan wasiat ini ada 2 (dua) hal yang perlu diperhatikan yaitu pertama, dalam pasal 897 KUH Perdata disebutkan bahwa seorang yang belum dewasa dan belum mencapai umur genap 18 tahun tidak boleh membuat wasiat. Kedua, dalam Pasal 888 KUH Perdata disebutkan bahwa jika dalam surat wasiat ada syarat yang tidak dapat dimengerti atau tidak mungkin dilaksanakan atau bertentangan dengan kesusilaan yang baik harus dianggap sebagai tidak tertulis. Jadi, dalam dua kasus di atas baik pengangkatan sebagai ahli waris maupun ketentuan pemberian hibah harus dimuat di dalam surat wasiat.

\section{Kewarisan Dalam Hukum Islam}

Hukum Islam Indonesia masa kini adalah merupakan sebuah label yang diberikan pada ketentuan hukum Islam yang berlaku di Indonesia dan sekaligus menampilkan corak khas keIndonesiaan. Sistem dan budaya Indonesia akan lebih terefleksi di dalamnya sehingga hukum Islam dimaksudkan untuk beberapa bagian tertentu baik yang menyangkut kaidah hukumnya maupun pola pemikiran yang mendasari, akan menunjukkan beberapa perbedaan dengan hukum Islam yang berlaku dalam kenyataan, sekalipun sifat dasarnya sama karena bersumberkan pada sumber yang sama yaitu al-Qur'an dan al-Hadits. Hukum Islam dengan daya antisipasinya yang tinggi telah menjadikan hukum ini sangat dinamis. ${ }^{21}$

Hukum Islam Indonesia masa kini masih belum terwujud sebagaimana diharapkan atau terpolakan secara jelas. Kompilasi Hukum Islam dianggap sebagai satu diantara sekian banyak karya besar umat Islam Indonesia dalam rangka kebangkitan umat Islam Indonesia, secara tidak langsung ia juga merefleksikan tingkat keberhasilan tersebut.

Kompilasi Hukum Islam meskipun oleh banyak pihak tidak diakui sebagai hukum perundang-undangan, namun pelaksana di Peradilan-peradilan Agama telah bersepakat untuk menjadikannya sebagai pedoman dalam berperkara di pengadilan. Dengan demikian Kompilasi

${ }^{21}$ Kemenag RI, Pelaksanaan Hukum Waris di Kalangan Umat Islam Indonesia (Jakarta: Maloho Jaya Abadi Press, 2010), 11.

196 | Falasifa, Vol. 11 Nomor 1 Maret 2020 
Hukum Islam bidang kewarisan telah menjadi buku hukum di lembaga Peradilan Agama. Jika dahulu hukum kewarisan berada dalam kitab-kitab figh yang tersusun dalam bentuk buku ajaran, maka saat ini, kompilasi tersebut telah tertuang dalam format perundang-undangan. Hal ini dilakukan untuk mempermudah hakim Peradilan Agama dalam merujuknya. ${ }^{22}$ Apakah dengan demikian hukum kewarisan dari fiqh mawarits atau faraid telah digantikan oleh Kompilasi Hukum Islam? Suatu hal yang dapat dipastikan adalah bahwa hukum kewarisan Islam selama ini yang bernama fiqh mawarits atau faraid dijadikan salah satu sumber utama dari kompilasi. Sumber lainnya adalah kenyataan yang berlaku di tengah masyarakat yang tertuang dalam yurisprudensi Pengadilan Agama.

Dari hasil penelitian terungkap bahwa tingkat pengetahuan dan ulama dan tokoh masyarakat terhadap Kompilasi Hukum Islam masih sangat rendah. Pandangan mereka dapat dikategorikan kepada ulama yang belum mengetahui Kompilasi Hukum Islam; ulama yang mengetahui tetapi tidak mendalami isi Kompilasi Hukum Islam; ulama yang mengetahui Kompilasi Hukum Islam secara mendalam. ${ }^{23}$ Oleh karena itu para ulama dan hakim agama mengusulkan agar materi Kompilasi Hukum Islam tetap dipertahankan, tetapi isi pasal-pasal perlu disempurnakan. Seperti pasal tentang harta bersama, ahli waris pengganti, halangan menerima warisan karena perencanaan pembunuhan dan fitnah, serta pencabutan pasal-pasal seperti pasal tentang $1 / 3$ bagian untuk ayah bila pewaris tidak punya anak dan pembagian warisan berupa tanah $<2$ ha; dan hak "ahli waris" berbeda agama, dan anak hasil perzinaan. ${ }^{24}$

Kompilasi Hukum Islam yang mengatur kewarisan terdiri dari 23 pasal, dari Pasal 171 sampai dengan Pasal 193. Dari pasal demi pasal yang berkenaan dengan ketentuan kewarisan dapat dikatakan bahwa pada umumnya pasal-pasal kewarisan dari Kompilasi Hukum Islam, meskipun disana sini terdapat perbedaan dengan kitab fiqh, dapat ditempatkan sebagai hukum kewarisan Islam dalam bentuknya yang baru. Hukum kewarisan Islam didasarkan kepada beberapa ayat al-Qur'an. Sebagian dari ayat- ayat kewarisan ini sudah begitu jelas dan pasti. Diantara ayat-ayat tersebut ada yang masih memerlukan penjelasan dari Nabi, baik dalam penjelasan arti, pembatasan maksud dan perluasan makna. Hukum kewarisan Islam yang didasarkan kepada wahyu Allah dan sabda Nabi adalah ajaran agama atau fikih yang tentang

\footnotetext{
${ }^{22}$ Amir Syarifuddin, Hukum Kewarisan Islam (Jakarta: Kencana, 2012), 309.

${ }^{23}$ Kemenag RI, Pelaksanaan Hukum Waris, 7-8.

${ }^{24}$ Ibid, 8.
} 


\section{Ipandang}

kewarisan yang harus dijadikan pedoman bagi umat Islam dalam menyelesaikan masalah harta peninggalan orang yang telah meninggal dunia.

\section{KESIMPULAN}

Ketentuan Pembagian Harta Waris untuk Anak Luar Nikah menurut KUH Perdata Kedudukan dan Akibat Hukum Pengakuan Anak Luar Nikah, Pengakuan anak merupakan pengakuan yang dilakukan oleh bapak atau ibu atas anak yang lahir di luar perkawinan yang sah menurut hukum. Pada dasarnya, pengakuan anak bisa dilakukan baik oleh ibu maupun bapak, tetapi karena berdasarkan Undang-undang No. 1 Tahun 1974 tentang Perkawinan Pasal 43 yang pada intinya menyatakan bahwa anak yang lahir di luar perkawinan tidak mempunyai hubungan perdata dengan bapaknya, maka untuk mendapatkan hubungan perdata yang baru, seorang bapak dapat melakukan pengakuan anak. Akibat dari pengakuan anak luar nikah ini terhadap orang tuanya adalah terjadinya hubungan perdata antara anak dengan bapak atau ibu yang mengakuinya. (a) Proses Pengakuan dan Pengesahan anak Luar Nikah. Dengan adanya pengakuan itu dapat mengakibatkan anak luar nikah mempunyai hak mewaris dari orang tuanya. Namun tidak semua anak luar nikah dapat memperoleh hak mewaris dari orang tuanya. Anak luar nikah yang dapat memperoleh hak mewaris dari orang tuanya adalah yang sesuai dengan Pasal 285 KUH Perdata yaitu "anak luar nikah yang dapat mewaris apabila anak luar nikah tersebut mendapat pengakuan dari bapaknya sebelum bapak yang melakukan pengakuan itu melangsungkan perkawinan sah dengan orang lain.” (b) Besarnya Bagian Warisan Anak Luar Nikah. Anak luar nikah yang diakui sebelum dilangsungkannya perkawinan orang tuanya dengan orang lain mewaris dengan semua golongan ahli waris. Besarnya bagian warisan yang diperoleh anak luar nikah yang diakui adalah tergantung dari dengan bersama-sama siapa anak luar kawin diakui itu mewaris (atau dengan ahli waris sah yang mana anak luar nikah yang diakui itu mewaris). (c) Hilangnya Bagian Warisan Anak Luar Nikah. Dalam KUH Perdata sebagaimana diatur dalam Pasal 838 maka seorang ahli waris akan kehilangan haknya apabila dia dengan keputusan hakim dihukum karena dipersalahkan telah membunuh atau mencoba membunuh orang yang meninggal (pewaris); apabila dia dengan putusan hakim pernah dipersalahkan karena secara fitnah telah mengajukan pengaduan terhadap orang yang meninggal; apabila dia dengan kekerasan atau pebuatan telah mencegah orang yang meninggal untu membuat atau mencabut surat wasiatnya; dan apabila dia telah menggelapkan, merusak atau memalsukan wasiat orang yang meninggal. 
Ketentuan Pembagian Harta Waris untuk Anak Luar Nikah menurut Kompilasi Hukum Islam: Pertama Kedudukan dan Akibat Hukum Pengakuan Anak Luar Nikah. Dalam hukum Islam sebagaimana diatur dalam Kompilasi Hukum Islam, kedudukan anak luar nikah yang diakui meskipun anak tersebut sudah diakui oleh bapaknya, anak tersebut tidak dapat saling mewaris dengan bapaknya. Hal ini karena menurut hokum Islam anak luar nikah merupakan anak zina, dimana anak zina hanya mempunyai hubunga hokum dengan ibunya dan kerabat ibunya saja. Kedua, Sebab-sebab Anak Luar Nikah Mendapat Warisan Seorang anak mendapatkan hak mewaris karena pernikahan, kekerabatan dan walaa'. Seorang anak luar nikah mendapatkan hak mewarisnyaa hanya dengan ibu dan kerabat dari ibunya karena hubungan kekerabatan saja. Namun anak luar nikah tersebut bisa mendapatkan hak mewarisnya dengan jalan wasiat. Ketiga, Besarnya Bagian Warisan Anak Luar Nikah. Dalam Kompilasi Hukum Islam ketentuan bagian warisan anak luar nikah hanya dijelaskan bahwa anak luar nikah akan mendapat warisan atau saling mewaris dengan ibunya saja dan dari keluarga ibunya, sehingga apabila dalam sebuah keluarga terdapat anak luar nikah maka ia dapat menutup ahli waris di bawahnya. Dari garis bapak anak luar nikah tidak mendapatkan pembagian warisan, meskipun harta warisan tersisa, harta warisan diserahkan kepada perbendaharaan Negara. Keempat, Hilangnya Bagian Warisan Anak Luar Nikah. Seorang ahli waris akan kehilangan hak mewarisnya karena perbudakan, karena pembunuhan, karena berlainan agama dengan si pewaris, karena murtad dan karena hilang tanpa berita. Dalam Kompilasi Hukum Islam sebagaimana diatur dalam Pasal 173 dijelaskan bahwa seseorang terhalang untuk menjadi ahli waris apabila dengan putusan hakim yang telah mempunyai kekuatan hokum tetap, dihukum karena dipersalahkan telah membunuh atau mencoba membunuh atau menganiaya berat pada pewaris dan karena dipersalahkan secara memfitnah telah mengajukan pengaduan bahwa pewaris telah melakukan suatu kejahatan yang diancam dengan hukuman 5 (lima) tahun penjara atau hukuman yang lebih berat.

Komparasi Tentang Pembagian Harta Waris Untuk Anak Luar Nikah Dalam KUH Perdata (Burgerlijk Wetboek) dan Kompilasi Hukum Islam. Pada dasarnya setiap hukum yang berlaku mengenai kewarisan mempunyai ketentuan atau pengaturan sendiri-sendiri mengenai batas-batas keadilan pembagian warisan. Demikian pula halnya dalam KUH Perdata (Burgerlijke Wetboek) dan Kompilasi Hukum Islam. Pada kedua peraturan tersebut terdapat persamaan dan perbedaan tentang ketentuan pembagian warisan kepada anak luar nikah. Namun meskipun 


\section{Ipandang}

mempunyai perbedaan, pada hakekatnya mempunyai tujuan yang sama yaitu keduanya bertujuan untuk memberikan kesejahteraan dan keadilan kepada anak luar nikah yang telah diakui.

\section{DAFTAR PUSTAKA}

Soesilo dan Pramudji R., Undang-undang RI No. 1 Tabu 1974 tentang Perkawinan, T.tp: Rhedbook Publisher, 2008.

Tim Pelaksana Pentashihan Mushaf al-Qur'an, Mushaf 'Aisyah: Al-Qur'an dan Terjemah untuk Wanita (Bandung: Hilal, 2010)

Rr. Murdiningsih, Tesis: Peranan Notaris, Jakarta: FH UI, 2009.

Abdul Manan, Aneka Masalah Hukum Perdata Islam Di Indonesia, Jakarta: Kencana Prenada Media, 2008.

Soesilo dan Pramudji R., Kitab Undang-undang Hukum Perdata, T.tp: Rhedbook Publisher, 2008. Tamakiran S., Asas-asas Hukum Waris Menurut Tiga Sistim Hukum, Bandung: Pionir Jaya, 2000.

M. Idris Ramulyo, Perbandingan Hukum Kewarisan Islam dengan Kewarisan Kitab Undang-undang Hukum Perdata Barat, Edisi Revisi, Jakarata: Sinar Grafika, 2004.

Anisitus Amanat, Membagi Warisan Berdasarkan Pasal-pasal Hukum Perdata BW, Jakarta: PT Raja Grafindo Persada, 2000.

Kemenag RI, Pelaksanaan Hukum Waris di Kalangan Umat Islam Indonesia Jakarta: Maloho Jaya Abadi Press, 2010.

Amir Syarifuddin, Hukum Kewarisan Islam, Jakarta: Kencana, 2012. 